\title{
Effective Factors on Agricultural Land Use Change in Guilan Province, Iran
}

\author{
Mohammad Sadegh Allahyari', \\ Azadeh Poshtiban², \\ Vikram Koundinya ${ }^{3}$
}

1,2Department of Agricultural Management, Rasht Branch, Islamic Azad University, Iran

${ }^{3}$ Agriculture and Natural Resources Extension, lowa State University, U.S.A.

\section{Doi:10.5901/mjss.2013.v4n11p744}

\section{Abstract}

To identify effective factors on agricultural land use changes in Guilan Province of northern Iran, a study with 320 experts of Agricultural Organization and Main Department of Natural Resources of Guilan's experts was done. This research was an applied research and descriptive. A questionnaire was the main research instrument. For determining the validity of the questionnaire, the face and content validity was used. Cronbach's alpha was used to measure the reliability of the instrument, which was 0.94 and showed the instrument reliability. Results showed that economic factors had the greatest impact on agricultural land use changes in Guilan followed by Social, management and policy making related, personal and technical factors. Of the selected economic factors, locating in the outskirts of cities and no justification about expenditure with revenue had the greatest impact of land use changes. Population growth and expansion of the physical part of the city was the most effective social factor in land use change. Lack of support for manufacturer from managerial and policy making factors and increasing age of farmers were among the individual factors also impacted land use change. Traditional production methods and changes in cropping patterns were technical and technological factors respectively had less impact compared to the identified economic, social, and managerial factors.

Keywords: land use, economic factors, social factors, managerial factors, technical factors, personal factors.

\section{Introduction}

Land and soil as the basic elements of human and plant life are gifts of God to man to optimize utilization and conservation of flora and fauna, and to ensure consistency of his generation (Land Affairs Organization, 2009). Land played an important role in comfort, safety, style, and quality of human life. Sociologically, origin of the earth and land exploitation has been major causes of social and legal issues, and conflicts between public and private interests (Hagh Sheno, 2007).

The Iranian agricultural sector is faced with serious challenges, with depleting soil base being one major one. Capital formation in agriculture sector is low and workforce employed largely lacks sufficient knowledge. Operational units are primarily not-economic and not-technical, and their production is small. The factors responsible for this situation need to be reviewed. Lack of production bases and lack of basic knowledge of the factors of production made the possibility of conserving the basic resources like soil very difficult. (Mohaghegh, 2003). Since the increase in food production required maintaining and developing agricultural land for national development, farmland preservation and expansion of agricultural lands are considered as the main goals. So the preservation of agricultural lands and orchards for self-sufficiency has increasingly received more attention (Akbari and Bezi, 2003). Food and Agriculture Organization (FAO) based on evaluating the nine Asian countries, in 1994, found Iran to have agricultural land and natural resources in the areas that are heavily eroded and destroyed (Yousefifard et al., 2007). The agriculture sector as a provider of food security and sustainable development is one of the key economic sectors in Iran, and contributes nearly 14\% of GDP, 31\% of non-oil exports, $23 \%$ of total employment and self-sufficiency rate of over $94 \%$ of agricultural products (Land Affairs Organization, 2009).

Following the enactment of the keeping usage of Land Act (1995), there are more than 140 thousand hectares of agricultural land with use change. Per hectare of agricultural land that is outside of the production circuit, a figure that is equivalent to 7-8 tons of the produce are diminished and for every 2-3 acres of agricultural land that is lost, at least a healthy employment in the agricultural sector is excluded that should investigate to make up for it in other areas (Land 
Affairs Organization, 2010). It is clear that changes in land use can lead to serious environmental problems (Parnun, 2010). Khakpour et al. (2007) stated that an example of the human impact on the environment is land use, and in order to plan and control the land and its development it is necessary to identify and evaluate factors influencing it. This study identifies factors affecting agricultural land use changes in Guilan Province of northern Iran.

Abelairas and Astorkiza (2012) mentioned that conversion of agricultural land to housing in rural areas that are closer to the city resulted in increased land prices. Long et al. (2007) called some management practices and their implications for political and administrative issues as main factors to build on agricultural land of China and land use change. Siciliano (2012) identified migration of villagers to the cities in search of better livelihood as the most important factor in land use change. Kroll and Haase (2010) predicted demographic change as one of the most important factors affecting land use changes in Europe. Wang et al. (2012) stated that 0.12 billion hectares of agricultural land in China cope with land use change when economic development began, and 13.55 percent of China's population is now faced with a shortage of land resources. Hagh Sheno et al. (2009) opined that low agricultural productivity and increased immigration lead to informal markets of housing and land use changes. The results showed that many farmers sold their lands, and areas with high costs and production areas have been converted into residential units. Monshi Zadeh and Khosh'hal (2005) stated economy to be one of the most important factors in deciding the type of land use. Further, they stated that activities and projects created to attract tourism also affect urban and rural land use change. Bicik et al. (2001) found that there were many social impacts that have been impressive in land use changes during $19^{\text {th }}$ and $20^{\text {th }}$ centuries. Farley et al. (2012) showed that enforcing new laws and taking control of lands leads to purchase and sale of land which makes deterioration of natural landscapes. Braimoh (2009) revealed that macro-economic changes in governments directly and indirectly impacted land use change in Ghana.

The main purpose of this study was to identify effective factors on agricultural land use changes in Guilan Province of northern Iran.

\section{Materials and Methods}

The study adopted a descriptive survey research design. Data were collected using a valid and reliable questionnaire. The first part of questionnaire collected demographic characteristics of experts including age, experience, gender, level of education, academic and organizational position. The second part of the questionnaire consisted of 39 statements based on the literature review; the variables that seemed to have the greatest impact on land use changes were made. Face and content validity of the questionnaire were established by an expert validation panel. Cronbach's alpha coefficient (0.94) was used to establish the reliability of the questionnaire. The population for this study consisted of experts from Agricultural Organizations in Guilan province like Department of Land Management, Extension Management, Soil and Water Management, Department of improving plant production, improve livestock production Department and Department of Natural Resources. A census of the population was conducted for this study. A total of 341 questionnaires was distributed, out of which 320 were returned to a response rate of $94 \%$. Data were analyzed using SPSS software. Descriptive statistical tools such as frequency distribution, mean, standard deviation and variation ratio and analytical tools like confirmatory factor analysis were used to analyze the data.

\section{Results}

Demographic findings revealed that the age group 40-49 years had the highest prevalence and age group 60-69 years had the lowest prevalence among the respondents (Table 1). The mean age of the respondents was 43.46 years. Respondents with experience of above 20 years and older had the highest prevalence and those with less than 5 years of experience had the lowest prevalence. The respondents' average work experience was 19.19 years. Of the 320 respondents, 268 (89.9\%) were male and 30 were female. Further, it was found that respondents with the highest degree of education (Master and above) had the highest prevalence and those with secondary education had the lowest prevalence. Two hundred and eleven respondents had agricultural major and 78 people had non-agricultural major. 
Table1, Frequency Distribution of respondents according to demographic characteristics

\begin{tabular}{|c|c|c|c|c|c|c|}
\hline Variable & $f$ & Percent & Valid percent & Cumulative percent & $\mathrm{M}$ & SD \\
\hline Age & & & & & 43.46 & 7.37 \\
\hline $20-29$ & 14 & 4.5 & 4.82 & 4.5 & & \\
\hline $30-39$ & 57 & 17.7 & 19.65 & 22.2 & & \\
\hline $40-49$ & 157 & 49.1 & 54.14 & 71.3 & & \\
\hline $50-59$ & 61 & 19.1 & 21.03 & 90.4 & & \\
\hline $60-69$ & 1 & 0.2 & 0.34 & 90.6 & & \\
\hline No respond & 30 & 9.4 & 10.34 & 100.0 & & \\
\hline Work Experience & & & & & 19.19 & 7.895 \\
\hline Less than 5 years & 22 & 7.4 & 7.4 & 7.4 & & \\
\hline $5-9$ & 27 & 8.4 & 8.4 & 15.8 & & \\
\hline $10-19$ & 74 & 23.0 & 23.0 & 38.8 & & \\
\hline 2 years later & 197 & 61.2 & 61.2 & 100.0 & & \\
\hline \multicolumn{7}{|l|}{ Sex } \\
\hline Woman & 30 & 9.4 & 10.1 & & & \\
\hline Man & 268 & 83.8 & 89.9 & & & \\
\hline No respond & 22 & 6.8 & - & & & \\
\hline \multicolumn{7}{|l|}{ Education } \\
\hline Diploma & 16 & 5.0 & 5.4 & 5.4 & & \\
\hline Resource & 36 & 11.3 & 12.1 & 17.5 & & \\
\hline Bachelor & 183 & 57.2 & 61.6 & 79.1 & & \\
\hline Master and above & 62 & 19.4 & 20.9 & 100.0 & & \\
\hline No respond & 23 & 7.1 & & & & \\
\hline \multicolumn{7}{|l|}{ Field of study } \\
\hline Agricultural & 211 & 65.9 & 73.0 & & & \\
\hline Non agricultural & 78 & 24.4 & 27.0 & & & \\
\hline No respond & 31 & 9.7 & & & & \\
\hline
\end{tabular}

In order to study the factors affecting agricultural land use change in Guilan, select variables were divided to five factors: economic, managerial and policy making, social, personal, and technical and technological factors using confirmatory factor analysis. Confirmatory factor analysis sorted out eight variables as economic factors. Accordingly, 7, 15, 4 and 5 factors were extracted as social, management and policy making, individual technical and technological factors, respectively.

Table 2, fitness indicators for factor analysis

\begin{tabular}{|l|l|c|c|c|}
\hline Row & Effective factors on land use change & KMO & Bartlet & P-value \\
\hline 1 & Economic & 0.681 & 290.9 & 0.000 \\
\hline 2 & Social & 0.638 & 267.55 & 0.000 \\
\hline 3 & Management and Policy & 0.765 & 811.41 & 0.000 \\
\hline 4 & Individual & 0.740 & 378.55 & 0.000 \\
\hline 5 & Technical and technological & 0.723 & 361.94 & 0.000 \\
\hline
\end{tabular}

Among the economic factors that affected agricultural land use change, being located in the outskirts of agricultural land and rising land prices with the highest average and high production costs and no justification of expenditure and revenue, had the greatest impact on agricultural land use change. Then, other variables such as low agricultural product prices, 
low income of rural farmers, and price volatility of agricultural products were the factors that had the highest average and were identified as important economic factors (Table 3).

Among the social factors affecting agricultural land use change, expansion of the physical aspect due to increase in population with the highest average is the most effective one. The trend of urbanization and escape from village life, rising unemployment and the desire to have a career in the city, to build houses for family, leaving their traditional agricultural occupation due to higher education of rural people are among the other factors that make the highest average according to respondents. Frequency distribution of management and policymaking factors that have an impact on land use change showed the lack of support for manufacturer is the most effective factor based on management and policy-making approach. The import of foreign products such as rice, land fragmentation due to inheritance law, lack of support for small farmers, increased rent and rental homes and need of private housing, were among the variables having a great impact on land use change. Hard work of farming is the most effective personal factors according to respondents.

The distribution of technical and technological factors affecting agricultural land use change in Gulian revealed that traditional production methods and no interest to farmers and involve in agricultural activities were the most effective factors. Changing the crop pattern was another factor that had a greater impact than any other factor. Overall, economic factors having the highest mean values were the most effective ones followed by social and management and policy making, interpersonal, and technical and technological factors affecting changes in agricultural land use in Guilan province in Iran.

Table3, Frequency distribution of factors influencing agricultural land use change in Guilan

\begin{tabular}{|c|c|c|c|}
\hline Rank & Effective factors on land use change & M & VR \\
\hline & Economic factors & 4.86 & \\
\hline 1 & $\begin{array}{l}\text { Lands located on the outskirts and rising up land prices tend to increase sales or use } \\
\text { changes. }\end{array}$ & 5.28 & 0.50 \\
\hline 2 & $\begin{array}{l}\text { High cost of production and not explains cost with revenue causes farmers have benefited } \\
\text { little from agricultural work and turned into non-agricultural activities. }\end{array}$ & 5.28 & 0.55 \\
\hline 3 & $\begin{array}{l}\text { Low prices for agricultural products increases wanting people to convert and land use } \\
\text { changes. }\end{array}$ & 5.20 & 0.58 \\
\hline 4 & $\begin{array}{l}\text { A low income rural farmer reduces motivation activity in the agricultural sector and farmers } \\
\text { in order to meet security requirements, become more motivated to use change. }\end{array}$ & 5.19 & 0.54 \\
\hline 5 & $\begin{array}{l}\text { Volatility of agricultural price increases tends to reduce agricultural and farmer thinks non- } \\
\text { agricultural use of land. }\end{array}$ & 4.82 & 0.58 \\
\hline 6 & Income in non-agricultural activities agricultural land use is motivation to change & 4.74 & 0.56 \\
\hline 7 & $\begin{array}{l}\text { The low productivity of rice production causes non-cultivated agricultural lands and } \\
\text { increases the desire for change. }\end{array}$ & 4.38 & 0.63 \\
\hline \multirow[t]{2}{*}{8} & $\begin{array}{l}\text { The products reduce destroys motivation agricultural activities and tends to change more } \\
\text { agricultural land. }\end{array}$ & 4.05 & 0.62 \\
\hline & Social factors & 4.81 & \\
\hline 1 & $\begin{array}{l}\text { Population increases spread town physical space and land use changes in outside of the } \\
\text { cities. }\end{array}$ & 4.62 & 0.62 \\
\hline 2 & $\begin{array}{l}\text { The trend of urbanization and escape from the village life causes land abandonment and } \\
\text { land use change. }\end{array}$ & 4.59 & 0.60 \\
\hline 3 & $\begin{array}{l}\text { Increase in unemployment and want to have good jobs in the city's cause's abandonment } \\
\text { agricultural lands and land use change. }\end{array}$ & 4.52 & 0.65 \\
\hline 4 & To need for a family part of agricultural land changes direction construction of houses & 4.37 & 0.70 \\
\hline 5 & Enhance rural education due to exit people from the traditional occupation of agriculture. & 3.88 & 0.65 \\
\hline 6 & $\begin{array}{l}\text { Seasonal labor lacks causes give up some parts of agriculture and context of use } \\
\text { changes. }\end{array}$ & 3.71 & 0.67 \\
\hline \multirow[t]{2}{*}{7} & Having multiple jobs produces land abandonment and land use changes over time. & 3.62 & 0.57 \\
\hline & Management and policy factors & 4.08 & \\
\hline 1 & Lack of support from the manufacturer causes purchase and sale of agricultural lands and & 5.16 & 0.59 \\
\hline
\end{tabular}




\begin{tabular}{|c|c|c|c|}
\hline & finally leads to land use changes. & & \\
\hline 2 & $\begin{array}{l}\text { The import of foreign products such as rice decreases the incentive of cultivates rice and } \\
\text { lead to land use change. }\end{array}$ & 4.72 & 0.61 \\
\hline 3 & $\begin{array}{l}\text { Inheritance law that due to shattered lands and uneconomical production and due to } \\
\text { gradually lands release and convert to non-cultivated and finally use changes occur. }\end{array}$ & 4.59 & 0.65 \\
\hline 4 & Lack of support for small farmers causes low motivation to work in the agricultural sector. & 4.45 & 0.66 \\
\hline 5 & $\begin{array}{l}\text { A rent increase of rental homes and the need for personal home cause changing } \\
\text { agricultural land to residential land. }\end{array}$ & 4.42 & 0.72 \\
\hline 6 & $\begin{array}{l}\text { Recommendations of some irresponsible and influential officials in nonagricultural projects } \\
\text { on of agricultural lands (packaging of mineral water, hotel, factories ...) causes' agricultural } \\
\text { land use changes. }\end{array}$ & 4.41 & 0.70 \\
\hline 7 & $\begin{array}{l}\text { Semiconductor project part of rural land overseas from production cycle and lead to land } \\
\text { use change. }\end{array}$ & 4.38 & 0.70 \\
\hline 8 & $\begin{array}{l}\text { Failure to maintain the law of agricultural and horticultural land because lack of adequate } \\
\text { facilities causes agricultural and horticultural land use change. }\end{array}$ & 4.33 & 0.67 \\
\hline 9 & Inefficient rules of user privacy cause land use change. & 4.15 & 0.69 \\
\hline 10 & $\begin{array}{l}\text { Dispersion and the number of agricultural parts causes descend efficiency in production } \\
\text { and finally land use change. }\end{array}$ & 4.13 & 0.63 \\
\hline 11 & $\begin{array}{l}\text { Failure of timely payment of damages by the agricultural insurance causes unwillingly of } \\
\text { farmers to cultivate and desire to land use change. }\end{array}$ & 3.93 & 0.75 \\
\hline 12 & $\begin{array}{l}\text { Performance of international initiatives for the construction of commercial ports and free } \\
\text { zones causes land use change. }\end{array}$ & 3.40 & 0.73 \\
\hline 13 & Implementation of land reform and land distribution causes land use change. & 3.33 & 0.73 \\
\hline 14 & $\begin{array}{l}\text { Government land and housing policies including Mehr housing causes agricultural land } \\
\text { use changes. }\end{array}$ & 3.23 & 0.72 \\
\hline \multirow[t]{2}{*}{15} & $\begin{array}{l}\text { Lack of passable water and necessary facilities to collect water in season's high water } \\
\text { caused land abandonment and changes in land use. }\end{array}$ & 3.16 & 0.64 \\
\hline & Individual factors & 4.01 & \\
\hline 1 & $\begin{array}{l}\text { Hard work due to agricultural activities caused farmer thought non-agricultural use of land } \\
\text { and land use change. }\end{array}$ & 4.18 & 0.63 \\
\hline 2 & $\begin{array}{l}\text { With increasing age of farmers reduces the ability to do agricultural work and desire for } \\
\text { change increased. }\end{array}$ & 4.10 & 0.68 \\
\hline 3 & $\begin{array}{l}\text { Old age and inability required for farm causes abandonment part of the land and land use } \\
\text { change. }\end{array}$ & 4.04 & 0.69 \\
\hline \multirow[t]{2}{*}{4} & $\begin{array}{l}\text { Illness and hard work in agricultural sector causes land abandonment and land use } \\
\text { change. }\end{array}$ & 3.74 & 0.68 \\
\hline & Technical and technological factors & 3.34 & \\
\hline 1 & $\begin{array}{l}\text { Traditional production methods and unwillingness to cultivation and agricultural work } \\
\text { causes non-agricultural use of soil. }\end{array}$ & 3.69 & 0.69 \\
\hline 2 & $\begin{array}{l}\text { Changes in cropping patterns cause convert and agricultural and horticultural land use } \\
\text { change. }\end{array}$ & 3.51 & 0.71 \\
\hline 3 & $\begin{array}{l}\text { Low knowledge and skill of plowing, irrigation and improper use of pesticides causes } \\
\text { changes in soil properties and land use change. }\end{array}$ & 3.49 & 0.70 \\
\hline 4 & $\begin{array}{l}\text { An improper tillage system causes loss and changes in physical and chemical properties } \\
\text { of soil. }\end{array}$ & 3.49 & 0.66 \\
\hline 5 & $\begin{array}{l}\text { Salinity of fertile soils and not having ability to cultivate causes loss part of the land use } \\
\text { change. }\end{array}$ & 2.54 & 0.64 \\
\hline
\end{tabular}

Based on the results of the comparison of average of factors affecting agricultural land use change in the Guilan according to respondents the highest average was related to economic factors, the second factor affecting land use changes with average of 4.81 related to social factors, the third factor with an average of 4.08 related to managerial policy making factors that affect land use change, according to the views of respondents, personal factor with an 
average of 4.01 is effective in land use change and technical and technological factors with the lowest average had the least effect on land use change.

\section{Discussion}

According to the results from the present study, the influence of economic factors on land use changes was the highest. The most important of these factors with the highest average were being located on outskirt of urban land and rising land prices, high production costs and lack of income justification, and low cost of agricultural products, the low income of rural farmers, agricultural prices and income instability and higher income in non-agricultural activities are all an expression of the economic problems of farmers and has provided areas for land use change. A profit making school of economics is a market that heavily influences the agricultural ecosystem. That is why owners and owners of agricultural lands and gardens generally with strong economic incentives are looking for land use change and using the other competing uses for the same space. Due to exposure to agricultural lands on outskirt of cities and the rising economic value of agricultural land in the poll was conducted, identified as the most important economic factors affecting land use change and we can note the benefit from the purchase and sale of the land to be granted to farmers, considering the low price of agricultural products and having no economic justification for some farmers causes no interest in agricultural activities and they become reluctant to sell farm lands or other construction such as factories, shops and homes on the land be taken. According to Abelairas and Astorkiza (2012), conversion of agricultural lands where prices are higher and rural areas close to the city lead people to have a willingness to pay high charges for conversion to residential land. Also, Monshi Zade and Khosh Hal (2005) found economic factors, as the most important factor in deciding the type of land use.

However, other problems such as lack of government subsidies and high costs of agricultural production, a lot of hard work and effort farmers do in the fields and the little profit that the farmer gets, decreases related motivation in this section. If the children of these people never do what their fathers did and seek other jobs with more benefits, including projects such as establishing industrial workshops, factories, shops, tourist sites or other activities related to agriculture such as poultry or fish ponds, which change the land use or sometimes it is possible to make land use changes by giving up the land. Volatility of agricultural prices while the survey was carried out is an important example of the land use change and it can be said due to the uncertainty of the farm product prices and input in a dusty atmosphere farmers make decisions because of uncertain import and export policies, price fluctuations and uncertainty of government support policies make farmers have no clear picture of their future and thus can't make a clear decision. Mismatch cost of sales and production, in addition to frustration on the part of farmers and activists of these events help brokers in the agricultural sector and farmers are forced to provide some money by selling wood products and struck it with the dealers sell at low prices. The above mentioned reasons make farmers to change their land use and to think about lucrative jobs and with higher economic benefits.

The second factors affecting land use change were social factors such as increasing urban population, migration and urbanization trends and escape from village life, rising unemployment and the need to build houses for habitat. In these social factors, youth unemployment and migrating from the countryside to find jobs in the cities or conversion of agricultural lands use to achieve high-income jobs could be the reason for the change. According to much research in this regard inside and outside the country shows the importance of this factor in the change of land use, so it can be concluded in recent years due to increasing population and urban expansion and pressure to expand urban and industrial areas, Greenland mostly cultivated land and garden areas around cities are extremely vulnerable to degradation and conversion. Krol and Hasse (2010) mentioned demographic change as one of the most important anticipated factors affecting land use changes in Europe.

The third factor affecting the land use change according to the respondents of this study was managerial and policy-making factors including the lack of support for the manufacturer, import of foreign products such as rice, inheritance law, which leads to land fragmentation and the non-economic production, the lack of support for small farmers, guiding plan, advise by some other not responsible authorities in performing non-agricultural projects, increased rent and rental homes and need to have a private mortgage can be named that lack of support for manufacturer has the highest distribution, So it seems the problems farmers face, such as lack of proper equipment, lack of proper warehouses for storage of rice including home depot and industrial warehouse which decrease the quality and quantity of rice yield, also, the lack of proper equipment for rice processing, failure to allocate the necessary funds to all led to lower rice production and need to be supported by government, otherwise profit from less agricultural work can motivate people to make changes to their agricultural land for other lucrative opportunities.

According to Long et al., (2007) some management practices and political consequences of changes in land use 
and management problems are reasons of land use change to residences in China. Another managerial factor affecting agricultural land use change is import of foreign rice products that reduce incentives for rice cultivation and it seems there is a need for more attention of government for domestic manufacturers in this field. In fact import should take place when a product is in short supply or not produced. However, when a product is being produced in the country there is no need to import it. Empowering farmers need to respect them for their efforts and provide the context that they did not pitch their products and at a suitable time sells products to market and take advantage of their efforts. Land fragmentation due to heredity is another factor that makes no economic gains. Land conservation laws inefficacy are one of those factors that are also found deficiencies in the law, including the Additional Note 4 of Article 1 of the Reform Act 2006, noted that issuing permits for agricultural activities (livestock, poultry, fish farming, processing and complementary industries and nurseries) to optimize agricultural department is not known as land use change. This note, first, leads people provide their plan in simple ways without observing the rules of transferring agricultural lands to perform those plans. Second, even those who destroyed agricultural lands such as paddy fields, tea plantations, orchards, berries and other agricultural lands (A or B grade) acting are top-notch. Also by virtue of Note 5 to Article 1 of the law, the lands located within the constitutional scheme of rural areas with guiding plan are subjected to the terms of any guiding plan excepted including law that this has caused more agricultural land to be in the guiding plan by people who change land use unauthorized. Therefore, there is a need that legislators review these laws.

Among personal factors influencing land use changes, increasing the age of farmers has the highest distribution that in this age the ability to perform agricultural labor is low and has more tendencies to make more land use change. However, due to being less important than other factors mentioned we can point to giving up the lands because of inability to farm with farmers aging that gradually land use change happens or they give lands to their children and due to no motivation some youth in rural areas and lack of economic justification of their farm may sell it or develop other nonagricultural jobs to the area. Among technical factors affecting land use changes, those with the highest distribution are related to changes in traditional production methods and cropping patterns that make conversion of arable and horticultural land use changes that have less impact in comparison to other factors. Adopting suitable cropping patterns based on related law continues to increase agricultural productivity and this can be a remedy. This model is based on each country's needs and priorities of strategic products and essential ones and evaluating the capacity of production in each region can be taken to prevent the indiscriminate land use changes that are related to these types of factors.

The factors that had the least impact on land use changes were fertile soil salinity which is among technical and technological factors and it is possible to have little lands with these characteristics due to a climate of Gulian and most soils there have suitable fertility. So we cannot consider it as a main reason of land use change. Performing land policies and housing given by government such as Mehr project, loss of enough water and essential facilities to collect water in water-filled seasons are among those factors that have less impact compared to other factors.

\section{Recommendations}

The following recommendations can be made based on the results from this study:

Since the economic incentives are among the most important factors influencing migration of labor from the agricultural sector, investment in the sector, subsidies, loans, guarantees the purchase of inputs and the fit between the actual cost of rice production, including those factors that will lead the farmers to crop strategic and necessary products. Or like in some countries that the government with setting prices and production levels declare the amount to farmers a year ago and farmers with a clear and conscious decision, attempt to grow next year.

Having written programs of import and export and support policies given by the government provide the basic needs of the country and prevent fluctuations of production and market price. It may also develop the agricultural sector and gaining goals of future views to develop a plan to increase exports of agricultural products, in line with expansion plans to increase production. Allocating the necessary funds for cultural activities is to promote public awareness of the importance of preserving agricultural land and to prevent unauthorized land use change, providing guidance and support to farmers to reduce production costs and increase their revenue.

Increased facilities for the villagers to prevent them from leaving their villages and farms and immigration, adoption and revision of a dynamic rules-based multilateral ones and Timely and appropriate implementation of laws to prevent the unauthorized land use change, increasing agricultural comparative advantage to other jobs, allocation exponentially taxes for non-agricultural land use, in order to protect the special land use allocation of preferential tax, This method presented in the form of subsidies to farmers to encourage them to protect agricultural land use. 
Consultants have limited development plans of rural areas to the construction and neighboring lands and prevent placing a wide range of agricultural land (rice paddies and orchards) in guiding plan limit.

Purchase of development rights by the government, the owner sells the right to government and he will be the owner of land but sells the right to keep the current land use.

Preparations of operating procedures such as a physical boundary between agricultural and non-agricultural use, adopt development strategies that are based on the protection of agricultural lands are done.

\section{References}

Astorkiza, I. \& Abelairas-Etxebarria, P. (2012). Farmland prices and land-use change in periurban protected natural areas. Land use policy, 29:674-68312.

Bezi, M., Akbari, M., (2004) Land ownership and exploitation systems in agriculture, Proceedings of the First Conference of Agricultural exploitation in Iran.

Bičík, I. Jeleček, L. Štěpánek, V. (2001). Land use change and their social driving forces in Czechia in the 19th and 20th centuries. Land use policy, 18: 65-73.13.

Braimoh, A. K. (2009). Agricultural land-use change during economic reforms in Ghana. Land Use Policy, 26(3), 763-771.

Farely, K. A., \& Ojeda-Revah, L. E. Atkinson, E. Eaton-González, B.R. (2012). Changes in land use, land tenure, and landscape fermentation in the Tijuana River watershed following reform of the Ejido sector. Land use policy. 29:187-197.

Hagh Sheno, M., Yazdani, S., Mehrabi, A., (2008) Factors affecting land use change and reviewing the social and economic effects of land use change (case study: Top Taleghan Region), Department of Economics and Development. Tehran University.

Khakpour, B., Velayati, S., Kia Nezhad, GH., (2005), pattern of land use change in Babol, from 1983-1999, Journal of Geography and Development of Geographical Area, 9 (5): 45-64.

Krausmann, F. Haberl, H. Schulz, NB. Ebr, KH. Darge, E. Gaube, V. (2003). Land-use change and socioeconomic metabolism in Austria-part I: Driving forces of land-use change: 1950-1995. Land use policy, 20: 1-20.15.

Land Affairs Organization (2009), Terms of Agrarian Reform, summarizes the determination and assignment of occupation of public lands.

Land Affairs Organization (2009), Series of laws and regulations to protect agricultural land and orchards.

Long, H. K. Heilig, G. Li, X. Zhang, M. (2007). Socioeconomic development and land-use change: Analysis of rural housing land transition in the Transect of the Yangtse River, China. Land use policy, 24:141-153.16.

Mohaghegh, M., (2003), Analysis of attitudes to preserve and protect agricultural land in the recent period and the required remedy. Proceedings of the First Conference of the agricultural operation in Iran.

Monshi Zadeh, R., Khosh hal, F., (2005) Impact of tourism on land use change in Lahijan (with an emphasis on rural land), Journal of Geographical Sciences. Beheshti University, Tehran. 4(5): 89-108.

Parnun, Z., (2009). Immigration Effects of Land Use Change in Islamshahr since 1966-2006, MS Thesis, University of Tehran, Department of Geography.

Siciliano, G. (2012). Urbanization strategies, rural development and land use change in China: A multiple level integrated assessment. Land use policy, 29:165-178.17.

Wang, J. Chen, Y. Shao, X. Zhang, Y. Co, Yingui. (2012). Land-use change and policy dimension driving force in China: Present, trends and future. Land use policy, 29:737-749.

Yousefi Fard. M., Khademi, H., Jalalian, A., (2007) Soil degradation during the change of land use in pasture region in Cheshme Ali in Chahar Mahal and Bakhtiari. Journal of Agricultural Sciences and Natural Resources. 14(1), 28 